\title{
KEBERTAHANAN PEMUKIMAN RUMAH PANGGUNG DI TEPIAN SUNGAI KAPUAS PONTIANAK
}

\author{
Ely Nurhidayati1,*, Trida Ridho Fariz ${ }^{2}$ \\ 1 Jurusan Perencanaan Wilayah dan Kota, Fakultas Teknik, Universitas Tanjungpura, \\ Jalan Prof Dr Hadari Nawawi Pontianak, 78124 \\ 2Program Studi IImu Lingkungan, Sekolah Pascasarjana, Universitas Gajah Mada, \\ Jalan Teknika Utara Yogyakarta, 55284 \\ *ely@untan.ac.id
}

\begin{abstract}
ABSTRAK
Pemukiman di tepian sungai Kapuas Pontianak telah mengalami perkembangan hampir dua setengah abad. Padahal wilayah tepian sungai memiliki kerentanan bencana banjir dan genangan yang paling parah terjadi pada pemukiman yang dekat dengan perairan. Gap penelitian ini adalah orang akan cenderung mencegah, menjauhi dan meninggalkan bermukim di daerah yang rentan bencana. Padahal penelitian sebelumnya menjustifikasi bahwa kebertahanan pemukiman Kampung Beting di tepian sungai Kapuas Pontianak berada pada kategori sangat tinggi. Penelitian ini terletak di Kelurahan Kampung Dalam Bugis dan Kelurahan Tambelan Sampit, Kecamatan Pontianak Timur, Kota Pontianak. Tujuan penelitian ini adalah menghasilkan model kebertahanan pemukiman rumah panggung di tepian sungai Kapuas Pontianak. Sedangkan sasarannya adalah menganalisis kebertahanan pemukiman rumah panggung di Kelurahan Kampung Dalam Bugis dan Kelurahan Tambelan Sampit. Metode penelitian yang digunakan adalah metode kuantitatif dengan pendekatan uji regresi stepwise method, uji anova, dan mendeskripsikan persamaan regresi yang dihasilkan. Teknik sampling yang digunakan adalah cluster sampling berjumlah 200 responden. Adapun variabel kebertahanan yang diukur adalah variabel sosial, ekonomi, masyarakat, dan infrastruktur perumahan. Hasil penelitian antara lain model kebertahanan di Kelurahan Kampung Dalam Bugis dipengaruhi oleh variabel sosial, ekonomi, masyarakat, dan infrastruktur pemukiman. Sedangkan model kebertahanan di Kelurahan Tambelan Sampit dipengaruhi oleh variabel sosial, ekonomi dan infrastruktur pemukiman.
\end{abstract}

Keywords: kerentanan, kebertahanan pemukiman, rumah panggung, sungai Kapuas.

\begin{abstract}
Settlements on the banks of the Kapuas river in Pontianak have been developing for almost two and a half centuries. Even though the river banks have the most severe vulnerability to flooding and innudation on settlements that are close to the waters. The research gaps is people will tend to prevent, stay away and leave settling in the area vulnerable to disasters. Though the previous research justifies the resilience in the Kampung Beting settlement on the banks of the Kapuas river in Pontianak, which is in the very high category. This research is located in Kampung Dalam Bugis Sub-District and Tambelan Sampit Sub-District, East Pontianak District, Pontianak City. The purpose of this study is to generate the resilience models of the stilts housing setllements on the banks of the Kapuas river in Pontianak. Whereas the goal is to analyze the resilience of the stilts housing setllements in Kampung Dalam Bugis Sub-District and Tambelan Sampit Sub-District. The research method used is a quantitative method with the stepwise regression test approach, ANOVA test, and describe the resulting regression equation. Sampling technique used is cluster sampling of 200 respondents. The resilience variables measured are the social, economic, community, and housing infrastructure variables. The results of the study is the resilience model in the Kampung Dalam Bugis Sub-District which is influenced by social, economic, community, and residential infrastructure variables. While the resilience model in the Tambelan Sampit Sub-District is influenced by social, economic, and residential infrastructure variables
\end{abstract}

Keywords: vulnerability, settlements resilience, stilts housing, Kapuas river. 


\section{PENDAHULUAN}

Keunikan permukiman di tepian sungai Kapuas di Pontianak adalah rumah panggung yang kini telah bertransformasi dari rumah lanting. Sampai saat ini pemukiman di tepian sungai telah mengalami perkembangan tempat tinggal secara turun-temurun (Hasanuddin, 2015). Hal yang menarik pada di lokasi penelitian ini adalah adanya risiko bencana ekologis yakni banjir pasang surut air laut yang banyak terjadi di topografi dataran rendah (Daniel dkk, 2005).

Faktanya risiko bencana banjir di Pontianak telah terjadi di sebagian wilayah Kecamatan Pontianak Timur. Penyebab utama banjir antara lain (Daniel dkk, 2005), sistem drainase yang buruk (0,237), pengurangan daerah resapan pembangunan perumahan $(0,219)$, timbunan sampah di sungai $(0,183)$, curah hujan tinggi $(0,104)$, pasang surut $(0,100)$, pendangkalan sedimen sungai $(0,092)$, topografi yang datar $(0,065)$.

Wilayah genangan yang terdapat di Kota Pontianak sebagaian besar merupakan genangan dalam jangka waktu yang singkat (1-2 jam), yang disebabkan oleh intensitas hujan yang tinggi. Terdapat beberapa lokasi dengan potensi genangan yang cukup luas, di antaranya mencakup kawasan penelitian yakni sebagian besar wilayah Pontianak Timur.

Hasil penelitian sebelumnya menjustifikasi bahwa kebertahanan masyarakat di pemukiman Kampung Beting, tepian sungai Kapuas Pontianak berada pada kategori sangat tinggi (Nurhidayati, 2016). Oleh karena itu, diperlukan penelitian lebih lanjut mengenai kebertahanan pemukiman rumah panggung di lokasi yang berbeda pada tepian Sungai Kapuas Pontianak, yaitu di Kelurahan Kampung Dalam Bugis dan Kelurahan Tambelan Sampit, Kecamatan Pontianak Timur, Kota Pontianak.

Data UNISDR (Badan Internasional Penanggulangan Bencana) menyebutkan, paparan terhadap penduduk atau jumlah manusia yang ada di daerah memungkinkan hilangnya nyawa. Oleh karena risiko bencana yang dihadapi Indonesia sangat tinggi (BNPB, 2016). Mengingat Pontianak memiliki topografi yang landai dengan tinggi 0,8 meter-1,5 meter dpl (di atas permukaan laut), menyebabkan Pontianak sangat rentan banjir, sehingga paparan terhadap kerentanan bencana sangat mungkin terjadi.

Perumahan dan pemukiman tepian sungai di Pontianak berkembang secara sporadis, serta mengikuti pola aliran sungai dan jaringan jalan. (Hasanuddin, 2015; Nurhidayati dkk, 2016). Perkembangan pemukiman tidak mampu mengimbangi pertumbuhan kota yang semakin cepat dan menuntut kepekaan yang tinggi terhadap lingkungan ekologis. Dalam hal ini, pemerintah tidak sensitif dalam merespon ketahanan sosial-fisik yang dibutuhkan. Ketidaksiapan dan kepekaan merespon lingkungan juga diperburuk dengan ketidakmampuan pemerintah memahami keutuhan satuan unit lingkungan (bioregion) dengan kebijakan-kebijakan lingkungan yang tersegregasi dan sektoral (Poerwoningsih et al, 2018). Kepekaan lingkungan salah satunya adalah pengetahuan tentang aspek keberlanjutan lingkungan, termasuk di dalamnya daya dukung lingkungan dan 
ketahanan bencana. Lebih dari 50\% masyarakat beranggapan bahwa pemimpin lokal harus memiliki pengetahuan dalam kesiapsiagaan bencana (Khailani dkk, 2013).

Kebertahanan didefinisikan sebagai rasio antara kesiapan dan kerentanan. Dimensi untuk kesiapan dapat bersifat sosial, ekonomi, kapasitas masyarakat, kelembagaan dan infrastruktur (World Bank, 2008; Kusumastuti dkk, 2014). Selain itu, kemampuan sistem sosial, ekonomi, dan lingkungan untuk menyerap perubahan (Jabareen, 2013; IPCC, 2014). Serta kemampuan untuk kembali kepada keadaan semula sebelum risiko bencana terjadi (Cutter dkk, 2008; Cutter dkk, 2014; Hung dkk, 2016; Khalili dkk, 2015; Joerin dkk, 2012; Usamah dkk, 2014). Definisi lainnya adalah kemampuan untuk mengantisipasi, mempersiapkan, menanggap, dan pulih dari ancaman bahaya dengan kerusakan yang minimal (U.S. National Research Council, 2010; World Bank, 2008).

Beberapa studi kasus kebertahanan (resilience) di pemukiman informal di Filipina menunjukkan adanya hubungan yang kuat antara kerentanan dan kebertahanan pada masyarakatnya. Hal ini disebabkan karena keduanya memiliki hubungan sosial yang erat dalam merespon kerentanan (Usamah dkk, 2014). Pada Model Baseline Resilience Indicators for Communities (BRIC) merumuskan variabel kebertahanan antara lain perumahan/infrastruktur, kelembagaan, kemampuan masyarakat dan lingkungan. Model ini digunakan untuk menilai kebutuhan dan program mitigasi (Cutter dkk, 2014; Usamah dkk, 2014).

Dari beberapa model penilaian kebertahanan dapat diuraikan bahwa Climate-related Disaster Community Resilience Framework (CDCRF) menilai kebertahanan masyarakat dalam menghadapi bencana banjir di masa yang akan datang. Masyarakat yang hidup di sekitar sungai memiliki risiko kerentanan yang lebih besar daripada tempat tinggal selain sungai. Model Net Vulnerability Resilience Index (NVRI) mengkaji gap antara kerentanan dan kebertahanan dengan pembangunan berkelanjutan (Angeon dkk, 2015; Joerin dkk, 2012).

Model Disaster Resilience of Place (DROP) digunakan untuk mengukur kebertahanan yang saling berkaitan antara aspek ekologi, sosial, ekonomi, kelembagaan, insfrastruktur dan masyarakat (Cutter dkk, 2008; Khalili dkk, 2015). Model Spatially Explicit Resilience-V ulnerability (SERV) digunakan untuk mengukur kerentanan tingkat daerah karena tingkat kerentanan berbeda-beda di tiap daerah. Sedangkan Principal Component Analysis (PCA) merupakan pendekatan untuk mengukur kebertahanan sistem bencana banjir, indikatornya antara lain aspek sosial, ekologi, infrastruktur dan ekonomi (Frazier dkk, 2014; Kotzee dkk, 2016). Sebagian besar kebertahanan masyarakat terletak di daerah dataran rendah atau rawan banjir. Kondisi sosial ekonomi berperan dalam menentukan kebertahanan, kemampuan masyarakat berpenghasilan rendah telah berkurang dalam merespon bencana (Daramola dkk, 2016; Hung dkk, 2016).

Dari model-model penilaian kebertahanan di atas, dapat ditarik kesimpulan bahwa pada umumnya kebertahanan pada risiko bencana genangan dan banjir memiliki tingkat kerentanan yang berbeda di tiap daerah disebabkan perbedaan variasi spasial. Dampak bencana banjir yang paling parah terjadi 
pada hunian yang dekat dengan perairan. Pada umumnya variabel kebertahanan terdiri atas variabel sosial, ekonomi, modal masyarakat, kebertahanan ekologi, institusi, dan infrastruktur (perumahan).

\section{METODE PENELITIAN}

Perumusan masalah penelitian dilakukan secara bertahap sebagai panduan dalam mengumpulkan data-data, menjaring data, analisis data, menemukan interpretasi data yang absah (Creswell dkk, 2010; Nazir, 1988; Moleong, 1993). Di luar negeri studi atau pengukuran kebertahanan telah banyak dilakukan (Kutanegara dkk, 2014), sedangkan penelitian ini mengukur kebertahanan non fisik khususnya masyarakat sebagai pelaku.

Analisis kebertahanan dilakukan dengan metode kuantitatif dengan pendekatan uji regresi stepwise method dan uji anova, kemudian menghasilkan persamaan regresi kebertahanan di Kelurahan Kampung Dalam Bugis dan Kelurahan Tambelan Sampit. Variabel yang diukur adalah variabel sosial, ekonomi, masyarakat, dan infrastruktur perumahan. Uji validitas bertujuan mengetahui apakah alat ukur yang digunakan memang tepat untuk mengukur perilaku kebertahanan masyarakat (Kutanegara, 2014). Teknik sampling yang digunakan adalah cluster sampling berjumlah 200 responden.

Variabel sosial, ekonomi, masyarakat, dan infrastruktur perumahan yang dianggap memberi pengaruh terhadap kebertahanan masyarakat di pemukiman rumah panggung tepian Sungai Kapuas Pontianak (Nurhidayati, 2016). Gap penelitian ini adalah bahwa orang akan cenderung mencegah, menjauhi dan meninggalkan bermukim di daerah yang rentan bencana (Genceer, 2013). Padahal pemukiman di tepian sungai Kapuas Pontianak telah dihuni secara turun-temurun selama hampir dua setengah abad (Hasanuddin, 2015).

\section{HASIL DAN PEMBAHASAN}

Penjelasan Gambar 1 bahwa wilayah perairan khususnya di tepian Sungai Kapuas Pontianak di Kelurahan Kampung Dalam Bugis dan Kelurahan Tambelan Sampit memilliki topografi dataran rendah, menjadi potensi ancaman bencana banjir/genangan yang tinggi, baik akibat pasang surut maupun kerusakan guna lahan di daerah hulu. Hal ini mendasari pentingnya penelitian tentang kebertahanan pemukiman di wilayah perairan yang rentan bencana banjir/genangan akibat pasang surut sungai.

Adapun indikator yang diperoleh mewakili masing-masing variabel. Variabel kebertahanan sosial antara lain, indikator kebiasaan menjaga kebersihan, kemudahan mendapatkan air, kemudahan penyediaan jaringan listrik, ketergantungan terhadap sumber daya air, kemudahan berbelanja, sosialisasi tentang kesehatan. Sedangkan variabel kebertahanan ekonomi antara lain, indikator kemudahan ke tempat kerja, rutinitas menabung, akses dari rumah ke tempat kerja, kesesuaian mata pencaharian, kecukupan pendapatan, ketergantungan pada sektor pekerjaan. 
Pada variabel kebertahanan masyarakat antara lain, indikator keterikatan hunian dengan pendatang, keterikatan hunian dengan penduduk asli, partisipasi masyarakat, persiapan menghadapi bencana, pengetahuan merespon terhadap bencana, keyakinan terhadap hukum alam, perolehan informasi bencana; kebersamaan antar warga. Pada variabel infrastruktur perumahan antara lain, indikator kenyamanan dan keamanan hunian, kualitas rumah, perbaikan prasarana jalan, penyediaan transportasi air, pengetahuan penghematan air.

Kebertahanan masyarakat di pemukiman rumah panggung tepian Sungai Kapuas Pontianak diduga dipengaruhi variabel sosial, ekonomi, masyarakat dan infrastruktur perumahan. Untuk mengetahui layak atau tidaknya keempat variabel tersebut menjelaskan kebertahanan, dilakukan uji stepwise untuk menunjukkan kelayakan setiap variabel. Secara bertahap menggunakan keempat model, regresi stepwise menguji variabel yang diduga memengaruhi kebertahanan. Model pertama hanya memasukkan variabel masyarakat, hasilnya menunjukkan variabel tersebut memenuhi syarat dan layak.

Model selanjutnya memasukkan variabel infrastruktur perumahan, hasilnya menunjukkan variabel tersebut memenuhi syarat dan layak. Hal ini juga terlihat pada model ketiga (sosial) hingga keempat (ekonomi) juga memenuhi syarat dan layak untuk diuji. Dengan demikian, keempat variabel yang diduga berpengaruh terhadap indeks kebertahanan memang layak digunakan untuk dianalisis. Terbukti hasil uji menunjukkan tidak terdapat variabel yang dikeluarkan (removed).
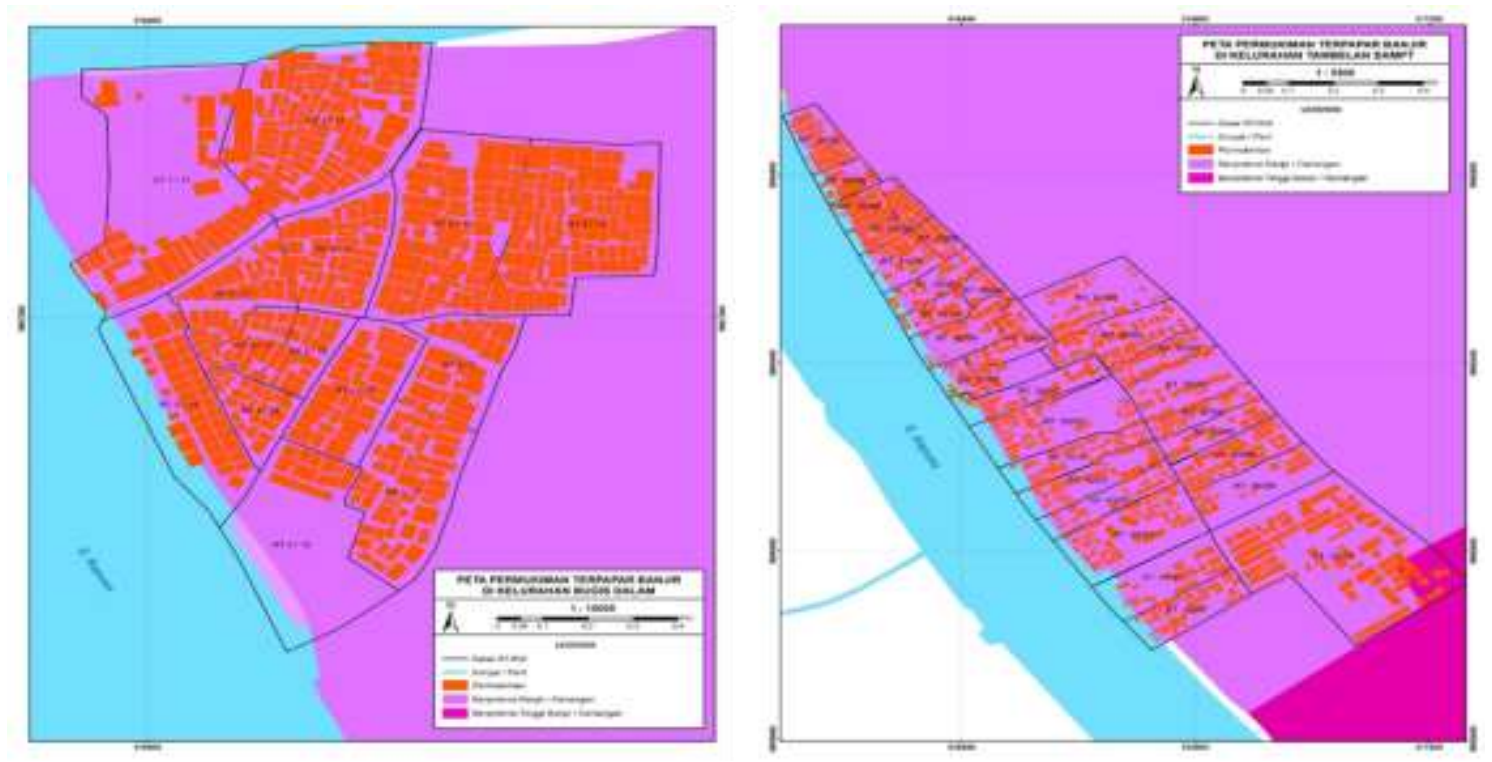

Gambar 1. Peta Pemukiman Terpapar Banjir (Sumber: Penulis, 2020) 


\section{MODEL KEBERTAHANAN DI KELURAHAN KAMPUNG DALAM BUGIS}

Berdasarkan uji ANOVA atau $\mathrm{F}$ test, model keempat yang akan digunakan karena memiliki nilai $\mathrm{F}$ sebesar 16,238 dengan signifikansi 0,000 yaitu jauh lebih kecil dari 0,05. Dari hasil tersebut dapat dijelaskan bahwa model regresi dapat digunakan untuk mengukur kebertahanan. Dengan kata lain, variabel sosial, ekonomi, masyarakat, dan infrastruktur perumahan secara bersama-sama memengaruhi kebertahanan masyarakat di Kelurahan Kampung Dalam Bugis yang merupakan pemukiman rumah panggung tepian Sungai Kapuas Pontianak.

$\mathrm{Y}=-0,168+0,145 \mathrm{X} 1+0,118 \mathrm{X} 2+0,058 \mathrm{X} 3+0,238 \mathrm{X} 4$

Dimana:

$\mathrm{Y}=$ Kebertahanan di Kelurahan Kampung Dalam Bugis

$\mathrm{X} 1=$ Sosial

$\mathrm{X} 2=$ Ekonomi

X3 = Masyarakat

$\mathrm{X} 4=$ Infrastruktur Perumahan

Model persamaan (1) diatas menunjukkan bahwa jika tidak ada variabel sosial, ekonomi, masyarakat, infrastruktur perumahan dan ekologi lingkungan adalah 0,168. Jika terjadi penambahan variabel sosial, ekonomi, masyarakat dan infrastruktur perumahan, akan menambah nilai indeks masingmasing sebesar $0,145,0,118,0,058$ dan 0,238 . Hasil uji regresi sebagaimana di susun pada model persamaan di atas juga memperlihatkan nilai konstanta negatif, artinya terdapat faktor di luar variabel di atas yang memengaruhi kebertahanan di Kelurahan Kampung Dalam Bugis, seperti misalnya faktor perilaku masyarakat.

Kebertahanan di Kampung Dalam Bugis dipengaruhi oleh variabel sosial, ekonomi, masyarakat, dan infrastruktur pemukiman. Infrastruktur pemukiman memiliki nilai paling tinggi dalam memengaruhi kebertahanan masyarakat, karena masyarakat sudah merasa nyaman dan betah tinggal di pemukiman rumah panggung, adanya perbaikan jalan gertak di pemukiman, adanya penyediaan transportasi air di pemukiman, dan pengetahuan masyarakat dalam memanfaatkan sumber daya air, baik itu air bersih dan air sungai.

Kebertahanan sosial menyangkut sistem alam, sistem sosial, dan lingkungan binaan yang saling terkait. Kebertahanan sosial menyangkut sistem sosial yang kompleks dan melibatkan unsur infrastruktur, tata kelola pemerintahan, ekonomi, sumber daya alam, karakter demografi dan interaksi sosial (Cutter dkk, 2008; Cutter dkk, 2014). Kebertahanan sosial di Kampung Dalam Bugis memiliki kelebihan sumber daya air sungai yang melimpah, akan tetapi tidak didukung oleh infrastruktur yang memadai perihal sumber air bersih. Selama ini interaksi sosial antara pendatang dan penduduk asli telah berlangsung lama, selain itu interaksi budaya masyarakat dalam memanfaatkan sungai untuk kehidupan sehari-hari. 
Terjadi kohesi sosial dan sense of community seperti adanya kontrol sosial, jaringan sosial, solidaritas sosial (Usamah dkk, 2014). Heterogenitas masyarakat di Kampung Dalam Bugis baik dari asal usul dan etnis menimbulkan akulturasi budaya yang dapat pudar. Misalnya warga keturunan Arab dan Melayu berbaur, maka akan lebih dominan ke Melayu. Kebertahanan sosial terjadi bilamana terdapat respon dan modal sosial dalam tiap individu untuk membantu tetangganya (Joerin dkk, 2012). Masyarakat di Kampung Dalam Bugis memiliki nilai kearifan lokal dalam aspek ditinjau dari kesamaan budaya dan agama, sehingga muncul kekerabatan, gotong royong dan sense of belonging terhadap kampung yang sama. Kebertahanan sosial dalam konteks kebencanaan tergantung pada situasi sosial dan respon masyarakat selama bencana dan pasca bencana. Kebertahanan sosial ditinjau dari kondisi sosial ekonomi yang erat dalam ketergantungan sosial dan pendapatan (Hung dkk, 2016), permasalahan di Kampung Dalam Bugis adalah persepsi masyarakat menganggap banjir bukan sebagai ancaman bencana, justru lebih sadar akan kemungkinan terjadinya benturan antar kelompok masyarakat.

Kebertahanan ekonomi ditinjau dari sektor mata pencaharian dan setiap individu dapat mengakses sumber daya alam (Cutter dkk, 2014), masyarakat yang tinggal dengan keadaan bentang alam sungai di pemukiman rumah panggung telah menyesuaikan diri dengan sektor mata pencaharian, seperti penyediaan transportasi sungai. Air sungai yang melimpah belum dapat secara maksimal meningkatkan taraf hidup masyarakat, akan tetapi sejak dikembangkannya Kampung Dalam Bugis sebagai destinasi wisata kampung air, perlahan dapat memaksimalkan fungsi sungai untuk meningkatkan taraf hidup perekonomian. Kebertahanan ekonomi di pemukiman informal terjadi pada masyarakat yang dapat berwirausaha menghasilkan pendapatan secara mandiri (Usamah dkk, 2014), tiga urutan terbesar jenis pekerjaan masyarakat adalah rumah tangga, buruh harian, dan wiraswasta. Masyarakat belum mandiri untuk menjadi wirausahawan di sektor primer dalam menciptakan lapangan pekerjaan untuk diri sendiri.

Kebertahanan masyarakat menyangkut tindakan manusia dan faktor luar seperti kebijakan dan peraturan yang dapat memberi pengaruh kuat pada kebertahanan masyarakat (Cutter dkk, 2008). Pemerintah belum memiliki legalitas formal terkait kebijakan bangunan yang berdiri di atas sungai. Hal ini akan berpengaruh positif terhadap kebertahanan masyarakat sebab rumah tersebut diperbolehkan untuk ditempati. Kebertahanan masyarakat selama bencana dan pasca bencana dipengaruhi oleh respon dan sosial bonding masyarakat (Usamah dkk, 2014), selama ini persepsi masyarakat tidak menganggap banjir sebagai bencana, sehingga respon dan sosial bonding berupa adaptasi menyerap keadaan lingkungan perairan sungai.

Kebertahanan infrastruktur perumahan terjadi pada fasilitas umum, cara merespon, kesiapan dan kapasitas dalam mengurangi risiko bencana (Hung dkk, 2016). Pengetahuan lokal masyarakat telah menjadi sumber pengetahuan lokal tentang cara menyerap risiko gengangan air akibat pasang surut sungai, pengetahuan lokal tersebut meliputi waktu pasut berlangsung, prediksi musim dapat mengetahui waktu pasang besar terjadi, ambang batas genangan yang perlu diwaspadai apabila air sungai berada diatas jalan gertak (kayu). 
Kebertahanan infrastruktur perumahan terkait dengan kualitas rumah dan sarana prasarana perkotaan yang memfasilitasi masyarakat terdampak bencana, sebenarnya kebertahanan lingkungan memiliki hubungan dengan daya serap lingkungan (Cutter dkk, 2014; Cutter dkk, 2008). Pemukiman rumah panggung masyarakat di Kampung Dalam Bugis hampir sebagian mengalami kerusakan bagian bawah (pondasi), daya serap lingkungan telah terjadi sekian lama akan tetapi masyarakat belum menyadari bahwa kondisi kronik dapat terjadi di lingkungan pemukimannya.

\section{MODEL KEBERTAHANAN DI KELURAHAN TAMBELAN SAMPIT}

Berdasarkan uji ANOVA atau $\mathrm{F}$ test, model ketiga yang akan digunakan karena memiliki nilai $\mathrm{F}$ sebesar 28,959 dengan signifikansi 0,000 yaitu jauh lebih kecil dari 0,05. Dari hasil tersebut dapat dijelaskan bahwa model regresi dapat digunakan untuk mengukur kebertahanan. Dengan kata lain, variabel sosial, ekonomi dan infrastruktur perumahan secara bersama-sama memengaruhi kebertahanan masyarakat di Kelurahan Tambelan Sampit yang merupakan pemukiman rumah panggung tepian Sungai Kapuas Pontianak.

$\mathrm{Y}=-3,913+0,175 \mathrm{X} 1+0,153 \mathrm{X} 2+0,279 \mathrm{X} 4 \ldots(2)$

Dimana:

$\mathrm{Y}=$ Kebertahanan di Kelurahan Tambelan Sampit

$\mathrm{X} 1=$ Sosial

$\mathrm{X} 2=$ Ekonomi

$\mathrm{X} 4=$ Infrastruktur Perumahan

Model persamaan (2) diatas menunjukkan bahwa jika tidak ada variabel sosial, ekonomi, masyarakat, infrastruktur perumahan dan ekologi lingkungan adalah -3,913. Jika terjadi penambahan variabel sosial, ekonomi dan infrastruktur perumahan, akan menambah nilai indeks masing-masing sebesar 0,175, 0,153 dan 0,279. Sedangkan variabel masyarakat tidak memiliki pengaruh terhadap kebertahanan karena memiliki nilai indeks nol. Hasil uji regresi sebagaimana di susun pada model persamaan di atas juga memperlihatkan nilai konstanta negatif, artinya terdapat faktor di luar variabel di atas yang memengaruhi kebertahanan di Kelurahan Tambelan Sampit.

Sedangkan kebertahanan di Tambelan Sampit dipengaruhi oleh variabel sosial, ekonomi, dan infrastruktur pemukiman. Tidak adanya pengaruh variabel masyarakat, karena peran serta masyarakat dari aspek keterikan tempat hunian antara warga asli dan pendatang, dukungan kegiatan pemerintah, persiapan dalam menghadapi bencana, pengetahuan dan cara merespon apilah terjadi bencana tidak menunjukkan pengaruhnya terhadap kebertahanan masyarakat.

Kebertahanan sosial menyangkut sistem alam, sistem sosial, dan lingkungan binaan yang saling terkait. Kebertahanan sosial menyangkut sistem sosial yang kompleks dan melibatkan unsur infrastruktur, tata kelola pemerintahan, ekonomi, sumber daya alam, karakter demografi dan 
interaksi sosial (Cutter dkk, 2008; Cutter dkk, 2014). Kebertahanan sosial di Tambelan Sampit memiliki kelebihan sumber daya air sungai yang melimpah, akan tetapi tidak didukung oleh infrastruktur yang memadai perihal sumber air bersih, sehingga masyarakat menampung air dengan fasilitas terbatas, misalnya melalui sambungan pia penyedot air dari sungai menuju rumah dan menggunakan bak penampung sementara. Saat ini wilayah tepian Sungai Kapuas telah dikembangkan sebagai tempat wisata, sehingga interaksi dapat terjadi antar warga lokal, dengan warga di luar kampung tersebut.

Terjadi kohesi sosial dan sense of community seperti adanya kontrol sosial, jaringan sosial, solidaritas sosial (Usamah dkk, 2014). Heterogenitas masyarakat di Tambelan Sampit baik dari asal usul dan etnis menimbulkan akulturasi budaya yang dapat pudar, hanya saja sebagian besar masyarakat adalah suku Melayu, berbeda halnya dengan di Kampung Dalam Bugis jumlah responden suku Arab masih lebih banyak daripada di Tambelan Sampit.

Kebertahanan sosial terjadi bilamana adanya respon dan modal sosial dalam tiap individu untuk membantu tetangganya (Joerin dkk, 2012). Masyarakat di Tambelan Sampit memiliki nilai kearifan lokal perihal kesamaan suku/ras yaitu Melayu. Kebertahanan sosial dalam konteks kebencanaan tergantung pada situasi sosial dan respon masyarakat selama bencana dan pasca bencana. Kebertahanan sosial ditinjau dari kondisi sosial ekonomi yang erat dalam ketergantungan sosial dan pendapatan (Hung dkk, 2016). Permasalahan di Tambelan Sampit sama halnya dengan yang terjadi di Kampung Dalam Bugis, yaitu tentang persepsi masyarakat yang menganggap banjir bukan sebagai ancaman bencana, hanya masyarakat telah sadar cara merespon keadaan alam apabila terjadi pasang air sungai diatas lantai rumah panggung.

Kebertahanan ekonomi ditinjau dari sektor mata pencaharian dan setiap individu dapat mengakses sumber daya alam (Cutter dkk, 2014), masyarakat yang tinggal di Tambelan Sampit didominasi jenis pekerjaan rumah tangga, buruh harian, dan wiraswasta. Jumlah buruh harian di Tambelan Sampit lebih banyak daripada jumlah buruh harian di Kampung Dalam Bugis. Kebertahanan ekonomi di pemukiman informal terjadi pada masyarakat yang dapat berwirausaha menghasilkan pendapatan secara mandiri (Usamah dkk, 2014), masyarakat yang bekerja sebagai buruh tani dan wiraswasta sedikit lebih banyak daripada Kampung Dalam Bugis.

Kebertahanan masyarakat menyangkut tindakan manusia dan faktor luar seperti kebijakan dan peraturan yang dapat memberi pengaruh kuat pada kebertahanan masyarakat (Cutter dkk, 2008). Kebertahanan masyarakat selama bencana dan pasca bencana dipengaruhi oleh respon dan sosial bonding masyarakat (Usamah dkk, 2014). Selama ini persepsi masyarakat tidak menganggap banjir sebagai bencana, sehingga respon dan sosial bonding berupa adaptasi menyerap keadaan lingkungan perairan sungai dan kedekatan sosial karena persamaan suku/ras.

Kebertahanan infrastruktur perumahan terjadi pada fasilitas umum, cara merespon, kesiapan dan kapasitas dalam mengurangi risiko bencana (Hung dkk, 2016). Pengetahuan lokal masyarakat telah 
menjadi sumber pengetahuan lokal tentang cara menyerap risiko gengangan air akibat pasang surut sungai. Pengetahuan lokal tersebut meliputi frekuensi waktu pasang surut, prediksi waktu pasang besar terjadi, ambang batas genangan yang perlu diwaspadai. Kebertahanan infrastruktur perumahan terkait dengan kualitas rumah dan sarana prasarana perkotaan, sebenarnya kebertahanan lingkungan memiliki hubungan dengan daya serap lingkungan (Cutter dkk, 2014; Cutter dkk, 2008). Masyarakat di pemukiman Tambelan Sampit mengalami kerusakan bagian panggung (pondasi), daya serap lingkungan telah berlangsung lama. Akan tetapi masyarakat belum menyadari bahwa kondisi kronik telah terjadi di lingkungan pemukimannya. Kerusakan pada struktur panggung (pondasi) rumah lebih banyak terjadi di Tambelan Sampit.

Penjelasan Gambar 2 bahwa pengukuran kebertahanan diduga dipengaruhi oleh variabel sosial, ekonomi, masyarakat, dan infrastruktur pemukiman. Kebertahanan di Kampung Dalam Bugis dipengaruhi oleh variabel sosial, ekonomi, masyarakat, dan infrastruktur pemukiman. Infrastruktur pemukiman memiliki nilai paling tinggi dalam memengaruhi kebertahanan masyarakat, karena masyarakat sudah merasa nyaman dan betah tinggal di pemukiman rumah panggung, adanya perbaikan jalan gertak (kayu) di pemukiman, adanya penyediaan transportasi air di pemukiman, dan pengetahuan masyarakat dalam memanfaatkan sumber air.

Kebertahanan pemukiman rumah panggung di Tambelan Sampit dipengaruhi oleh variabel sosial, ekonomi, dan infrastruktur pemukiman. Tidak adanya pengaruh variabel masyarakat, karena peran serta masyarakat dari aspek keterikatan tempat hunian antara warga asli dan pendatang, dukungan kegiatan pemerintah, persiapan dalam menghadapi bencana, pengetahuan dan cara merespon apabila terjadi bencana tidak menunjukkan pengaruhnya terhadap kebertahanan masyarakat. Sedangkan kebertahanan pemukiman rumah panggung di Tambelan Sampit dipengaruhi oleh variabel sosial, ekonomi, dan infrastruktur pemukiman. Tidak adanya pengaruh variabel masyarakat, karena peran serta masyarakat dari aspek keterikatan tempat hunian antara warga asli dan pendatang, dukungan kegiatan pemerintah, persiapan dalam menghadapi bencana, pengetahuan dan cara merespon apabila terjadi bencana tidak menunjukkan pengaruhnya terhadap kebertahanan masyarakat.

Model kebertahanan di pemukiman rumah panggung tepian Sungai Kapuas Pontianak membuktikan bahwa variabel sosial, ekonomi, masyarakat, dan infrastruktur perumahan berpengaruh terhadap kebertahanan pola pemukiman rumah panggung tepian Sungai Kapuas Pontianak. Indikator masing-masing variabel antara lain, pada variabel sosial terdiri dari kebiasaan menjaga kebersihan, kemudahan mendapatkan air, kemudahan penyediaan jaringan listrik, ketergantungan terhadap sumber daya air, kemudahan berbelanja, sosialisasi tentang kesehatan. Variabel kebertahanan ekonomi terdiri dari, kemudahan ke tempat kerja, rutinitas menabung, akses dari rumah ke tempat kerja, kesesuaian mata pencaharian, kecukupan pendapatan, ketergantungan pada sektor pekerjaan. 
Sedangkan variabel kebertahanan masyarakat terdiri dari, keterikatan hunian dengan pendatang, keterikatan hunian dengan penduduk asli, partisipasi masyarakat, persiapan menghadapi bencana, pengetahuan merespon terhadap bencana, keyakinan terhadap hukum alam, perolehan informasi bencana, kebersamaan antar warga. Variabel infrastruktur perumahan terdiri dari, kenyamanan dan keamanan hunian, kualitas rumah, perbaikan prasarana jalan, penyediaan transportasi air, pengetahuan pemanfaatan sumber daya air.

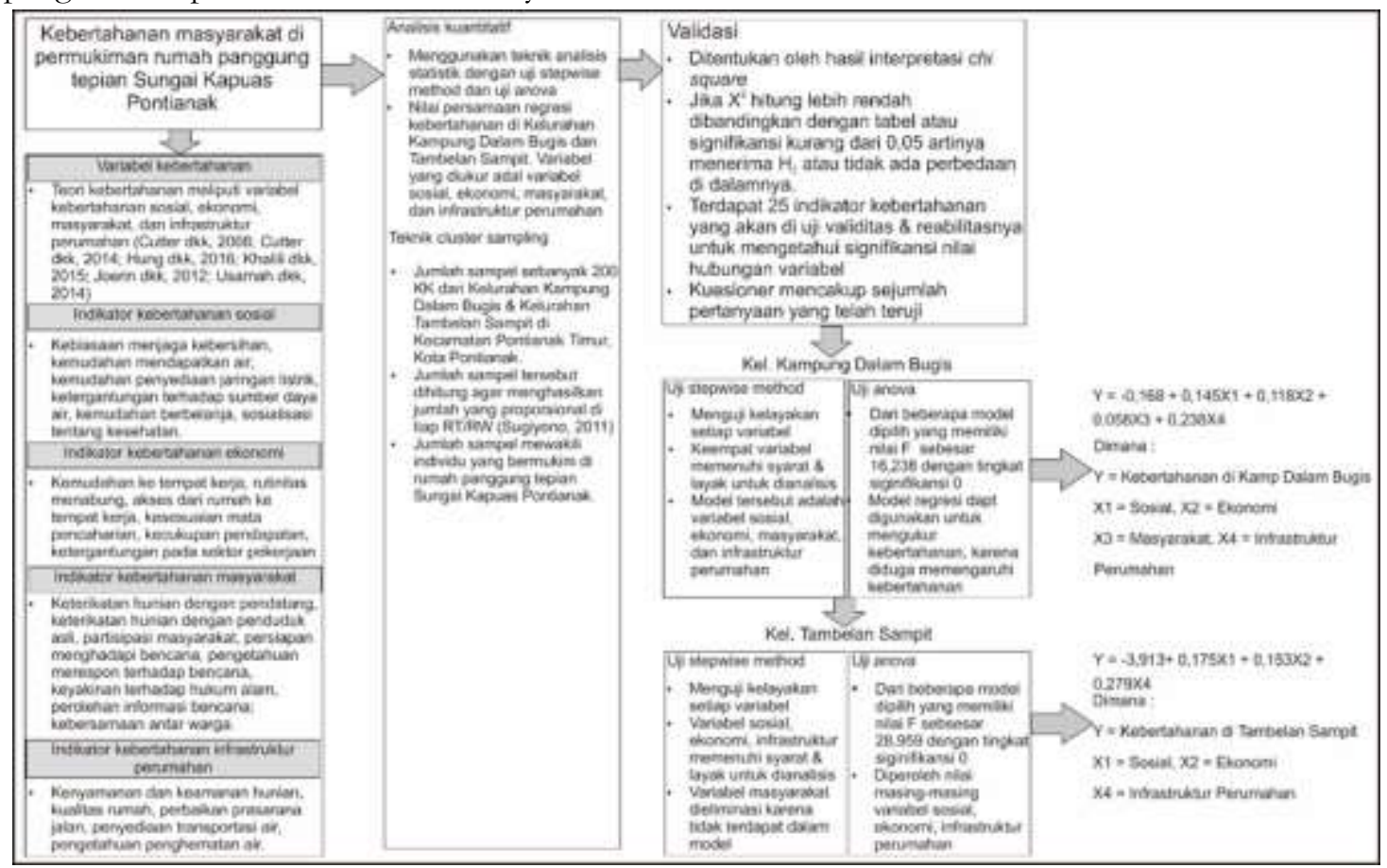

Gambar 2. Model Kebertahanan (Sumber: Penulis, 2020)

Sedangkan variabel kebertahanan masyarakat terdiri dari, keterikatan hunian dengan pendatang, keterikatan hunian dengan penduduk asli, partisipasi masyarakat, persiapan menghadapi bencana, pengetahuan merespon terhadap bencana, keyakinan terhadap hukum alam, perolehan informasi bencana, kebersamaan antar warga. Variabel infrastruktur perumahan terdiri dari, kenyamanan dan keamanan hunian, kualitas rumah, perbaikan prasarana jalan, penyediaan transportasi air, pengetahuan pemanfaatan sumber daya air.

\section{SIMPULAN}

Kebertahanan di Kelurahan Kampung Dalam Bugis dipengaruhi oleh variabel sosial, ekonomi, masyarakat, dan infrastruktur perumahan. Sedangkan kebertahanan masyarakat di Kelurahan Tambelan Sampit dipengaruhi oleh variabel sosial, ekonomi, dan infrastruktur perumahan. Terdapat variabel lain di luar variabel diatas yang memengaruhi kebertahanan di pemukiman rumah panggung tepian Sungai Kapuas Pontianak, yaitu perilaku dan keyakinan masyarakat terhadap hukum alam 
(sunnatullah) dalam menghadapi risiko kerentanan bencana di pemukiman tepian Sungai Kapuas Pontianak.

Kebertahanan dapat muncul akibat persepsi bencana yang dianggap sebagai bagian dari kehidupan masyarakat (Usamah dkk, 2014). Begitu pula yang terjadi pada masyarakat di pemukiman rumah panggung tepian Sungai Kapuas Pontianak bahwa banjir bukan sebagai bencana karena masyarakat memang tidak mengartikan sebagai bencana akan tetapi pasang surut sungai yang berlansung setiap hari. Kebertahanan tingkat terendah terdapat pada aspek infrastruktur perumahan, kelembagaan, modal masyarakat dan lingkungan (Cutter dkk, 2014). Sedangkan pada aspek infrastruktur perumahan dan lingkungan, kebertahanan berada pada tingkat tertinggi di pemukiman rumah panggung tepian Sungai Kapuas Pontianak.

Menurut Joerin dkk (2012), kebertahanan fisik, sosial, dan ekonomi masyarakat yang hidup di sekitar sungai dan kanal, berada pada risiko bencana paling tinggi. Menurut Daramola dkk (2016), hunian yang dekat dengan sumber air memiliki efek negatif terparah terhadap kerentanan bencana. Sedangkan menurut Kotzee dkk (2016), kebertahanan terhadap bencana banjir yang terendah berada di pinggiran kota seperti di lokasi pemukiman informal. Akan tetapi, kondisi eksisting di lapangan menunjukkan bahwa masyarakat di pemukiman rumah panggung tepian Sungai Kapuas Pontianak yang terletak di pinggiran Kota Pontianak, telah bermukim secara turun-temurun dan betah menetap selama hampir dua setengah abad.

Pengetahuan masyarakat lokal menunjukkan bahwa peran tokoh masyarakat berperan dalam menghadapi kerentanan bencana (Khailani dkk, 2013). Sedangkan pengetahuan lokal masyarakat asli di pemukiman tepian Sungai Kapuas Pontianak telah lama terbentuk sehingga menjadi bagian dari sumber pengetahuan masyarakat asli setempat. Peran sosial dan ekonomi menentukan kebertahanan dalam merespon dan pulih dari bencana (Hung dkk, 2016), akan tetapi peran sosial, ekonomi, masyarakat, dan infrastruktur perumahan dalam menentukan kebertahanan di pemukiman rumah panggung di tepian Sungai Kapuas Pontianak.

\section{REFERENSI}

Angeon, V., \& Bates, S. (2015). Reviewing Composite Vulnerability and Resilience Indexes: A Sustainable Approach and Application. World Development, 72, 140-162. https://doi.org/10.1016/j.worlddev.2015.02.011

Bank, W. (2008). Climate Resilient Cities: A Primer on Reducing Vulnerabilities to Climate Change Impacts and Strengthening Disaster Risk Management in East Asian Cities. Policy Paper. https://doi.org/10.1596/978-0-8213-7766-6

BNPB. (n.d.). Definisi dan Jenis Bencana. Retrieved from http://www.bnpb.go.id/pengetahuanbencana/definisi-dan-jenis-bencana

Cutter, S. L., Ash, K. D., \& Emrich, C. T. (2014). The geographies of community disaster resilience. Global Environmental Change, 29, 65-77. https://doi.org/10.1016/j.gloenvcha.2014.08.005

Cutter, S. L., Barnes, L., Berry, M., Burton, C., Evans, E., Tate, E., \& Webb, J. (2008). A placebased model for understanding community resilience to natural disasters. Global Environmental 
Change, 18(4), 598-606. https://doi.org/10.1016/j.gloenvcha.2008.07.013

Daniel, Meddy, M., Stefanus, B., Azwansyah, \& Heri. (2005). Penentuan Lokasi Banjir Tertinggi Kota Pontianak Dengan Pendekatan Matematis Linier: Laporan Penelitian. Fakultas Teknik Universitas Tanjungpura.

Daramola, A. Y., Oni, O. T., Ogundele, O., \& Adesanya, A. (2016). Adaptive capacity and coping response strategies to natural disasters: A study in Nigeria. International Journal of Disaster Risk Reduction, 15, 132-147. https://doi.org/10.1016/j.ijdrr.2016.01.007

Frazier, T. G., Thompson, C. M., \& Dezzani, R. J. (2014). A framework for the development of the SERV model: A Spatially Explicit Resilience-Vulnerability model. Applied Geography, 51, 158172. https://doi.org/10.1016/j.apgeog.2014.04.004

Hasanuddin. (2015). Sejarah Kota Pontianak Masa Kolonial. Yogyakarta: Ombak.

Hung, H.-C., Yang, C.-Y., Chien, C.-Y., \& Liu, Y.-C. (2016). Building resilience: Mainstreaming community participation into integrated assessment of resilience to climatic hazards in metropolitan land use management. Land Use Policy, 50, 48-58. https://doi.org/10.1016/j.landusepol.2015.08.029

Jabareen, Y. (2013). Planning the resilient city: Concepts and strategies for coping with climate change and environmental risk. Cities, 31, 220-229. https://doi.org/10.1016/j.cities.2012.05.004

Joerin, J., Shaw, R., Takeuchi, Y., \& Krishnamurthy, R. (2012). Assessing community resilience to climate-related disasters in Chennai, India. International Journal of Disaster Risk Reduction, 1, 44 54. https://doi.org/10.1016/j.ijdrr.2012.05.006

Khailani, D. K., \& Perera, R. (2013). Mainstreaming disaster resilience attributes in local development plans for the adaptation to climate change induced flooding: A study based on the local plan of Shah Alam City, Malaysia. Land Use Policy, 30(1), 615-627. https://doi.org/10.1016/j.landusepol.2012.05.003

Khalili, S., Harre, M., \& Morley, P. (2015). A temporal framework of social resilience indicators of communities to flood, case studies: Wagga wagga and Kempsey, NSW, Australia. International Journal of Disaster Risk Reduction, 13, 248-254. https:// doi.org/10.1016/j.ijdrr.2015.06.009

Kotzee, I., \& Reyers, B. (2016). Piloting a social-ecological index for measuring flood resilience: A composite index approach. Ecological Indicators, 60, 45-53. https://doi.org/10.1016/j.ecolind.2015.06.018

Kusumastuti, R. D., Viverita, Husodo, Z. A., Suardi, L., \& Danarsari, D. N. (2014). Developing a resilience index towards natural disasters in Indonesia. International Journal of Disaster Risk Reduction, 10(PA), 327-340. https:// doi.org/10.1016/j.ijdrr.2014.10.007

Nurhidayati, E., Imam Buchori., and Mussadun. 2016. The Water Based Urban Development in Pontianak: A Review The History of Riverine Settlements. The 1st Geoplanning International Conference.

Nurhidayati, E., Imam Buchori., and Mussadun, 2016. Prediksi Perkembangan Lahan Permukiman Terhadap Kerentanan Bencana Banjir dan Kebakaran di Permukiman Tepian Sungai Kapuas Kota Pontianak. Jurnal Tata Loka. Volume 18 (No 4): 249-260.

Nurhidayati, E. 2016. The Resilience of Rumah Panggung's Settlements in the Kapuas Riverbanks of Pontianak. $5^{\text {Th }}$ International Conference in Urban Heritage and Sustainable Infrasctructure Development.

Poerwoningsih, D., Santoso,I., Laksmiani, E. (2018). Konsep Bioregion Dalam Pengelolaan Sumberdaya Lansekap Arsitektur Nusantara. Mintakat Jurnal Arsitektur, 19(1). 49-58.

U.S. National Research Council. (2010). Adapting to the Impacts of Climate Change. 
Usamah, M., Handmer, J., Mitchell, D., \& Ahmed, I. (2014). Can the vulnerable be resilient? Coexistence of vulnerability and disaster resilience: Informal settlements in the Philippines. International Journal of Disaster Risk Reduction, 10, 178-189. https://doi.org/10.1016/j.ijdrr.2014.08.007

Usamah, M., Handmer, J., Mitchell, D., \& Ahmed, I. (2014). Can the vulnerable be resilient? Coexistence of vulnerability and disaster resilience: Informal settlements in the Philippines. International Journal of Disaster Risk Reduction, 10, 178-189. https://doi.org/10.1016/j.ijdrr.2014.08.007 